\title{
Lesson Study: Enhancing the Teaching and Learning of History Subject
}

\author{
Noor Izatul Hanim Md Rashadi ${ }^{1} \&$ Abdul Razak Ahmad $^{2}$ \\ ${ }^{12}$ Faculty of Education UKM, MALAYSIA \\ E-mail: $\underline{\text { hanimracd@gmail.com }}$
}

\begin{abstract}
This concept paper purposely to discuss the importance of Lesson Study practices in teaching and learning process of History subject. History teachers have to play an important role to create an effective teaching and learning method. They should apply various methods and techniques to create an impressive teaching and learning process and giving an opportunity for students to participate actively without feeling disinterested. The knowledge to diversify the teaching and learning methods will intensify the students' performance and changing their attitudes and interests towards History subjects which have been known as bored subject all this time. Because there are problems that arise among History teachers as not creative to prepare the Daily Lesson Plan and still tied to traditional patterns of practice, more creative and innovative teaching processes are needed to create effective teaching and learning processes. Thus, the Lesson Study is seen as a new approach to upgrade and increase the professionalism of History teachers. Teaching via Lesson Study will make History teachers more prepared while the students will get more effective learning sessions. The involvement of History teachers in Lesson Study will help to increase knowledge, Historical Thinking Skills, and creativity. This collaboration method can be implemented throughout group discussion and research study and discuss any problems arise in the teaching process. It is also able to create a conducive teaching and learning environment. Next, this concept paper will list several suggestions for improving Lesson Study in History subject. It has been targeted that Lesson Study can be applied to ensure that positive impact happens among students as well as teachers.
\end{abstract}

Keywords: Lesson Study, History, teaching and learning.

\section{Introduction}

History Education in Malaysia is an important discipline in making the individual who loves the country. It can also create a sense of unity among the multiracial society. Therefore, History subjects are so important that they become a core subject and compulsory to be taken by every student in the country starting in 1989 (Rajamani P \& Anuar Ahmad, 2017). As the country's education progresses, the History curriculum continues to receive attention from the authorities. This is proven when the Ministry of Education Malaysia has made History subject as one of the compulsory subjects to pass at the Malaysian Certificate of Education level in 2013 (Norakma Mohd Daud et.al 2015). This 
progress is seen to have given the equivalent status of History subjects the same as the other core subjects. The efforts by the Ministry of Education Malaysia to set up a Special Committee to Study the History Curriculum in secondary schools are very relevant (Ahamad \& Sidek, 2012). This is to ensure that the curriculum that will truly impact the understanding and appreciation of History more thoroughly among students. Various programs and innovations in the History curriculum are conducted to address issues related to History education.

Various issues arise in History education in Malaysia. This includes the weaknesses of History teachers in implementing the teaching and learning process. History teachers are often seen as implementing teacher-centered methods in their teaching and learning process. History teaching is more one-way style, not creative and does not create interaction between teachers and students (Sharipah \& Arba'iyah, 2016). A study by Malar M, (2010) shows that $85 \%$ of History teachers prefer to apply teacher-centered methods in the History teaching and learning process. This will cause students less focus on teacher and at the same time, students will lead to boredom and lose interest in History subjects (Rafidah Yulo \& Abdul Razak Ahmad. 2019). Students will assume that the History subject is only to memorize the historical facts. Students will also lose focus because they are not engaging in any activity but just listening to the History teacher explanations in front of the class. Most students today are not interested in sitting and listening to lectures from teachers for a long time. This is becoming more complicated as History teachers lack the skills in keeping with the latest era in teaching and learning. Besides that, the lack of History options teachers has also raised issues in History education. This is because nonoptional teachers do not have extensive knowledge of History subject. This will cause the teacher to feel burdened and cause the teaching and learning process to fail to achieve the set objectives. Non-optional teachers will also tend to implement the only teacher-centered teaching and learning processes only. They are also tied to textbook use only (Sharipah \& Arba'iyah, 2016). Besides, the issue that arises in History education is that History teachers did not plan well in completing the syllabus (Norakma Mohd Daud et.al 2015). The failure of teachers to plan well will also cause the content of the syllabus to fail to deliver effectively. These weaknesses may cause the teachers to start choosing to teach only those topics that they find important. Various issues arising in History education have made the process of teaching and learning History subject less effective.

As various issues arise in History education that makes it difficult for History teachers to achieve the objectives in the teaching and learning process, a new approach has been introduced to assist History teachers to be more prepared. History teachers will carry out the teaching and learning process via collaboration to achieve the set objectives. History teachers will discuss and study the issues that arise in the teaching process before initiate the teaching and learning process. This collaborative method will involve all members of the History Committee to ensure that all issues that arose in History education will be addressed. This collaborative method is named Lesson Study. This method proved to be effective when Rohaiza Abd Thani \& Norasmah Othman, (2017) conducted a study on the comparison of teaching effectiveness between teachers who had conducted Lesson Study and teacher who did not. The study was conducted on assessment aspects of teaching strategies, teaching aids, questioning techniques, and classroom control. Findings show that teachers who practice Lesson Study will have higher skills in teaching strategies, preparation of teaching aids, classroom control skills than teachers who did not conduct the Lesson Study. The study also recognized two factors that cause the Lesson Study being able to help teachers improve their teaching which is reflective session and collaborative practice.

\section{Lesson Study}

Lesson Study is a model of teacher professional development that has been pioneered and practiced by teachers in the Japan education system. It is collaboratively implemented during the teaching and learning process in the classroom by focusing on student learning. Lesson Study in Japanese is called 'Jugyokenkyu'. 'Jugyo' means study while 'Kenkyu' means investigation or research. This means that Lesson Study is a study and research on teachers' teaching process in the classroom by concentrating on student learning (Zanaton et al. 2017). While in this research, Lesson Study means research and review about teachers' actions collaboratively to determine learning goals and objectives, plan and prepare the Daily Lesson Plan, conduct classroom teaching and observation, implement teacher assessment and reflection of teacher' learning as well as improve the Daily Lesson Plan and re-teaching based on five cycles in Lesson Study (Nur Ain Elzira \& Zamri, 2019). According to Zanaton et al. (2017), the starting and development of Lesson Study in other countries began when world educationalist began to pay attention to the outcomes of the Third International Mathematics and Sciences Study (TIMSS) video study in 1995. These video studies involved three countries, the United States, Germany and Japan which became a surprise when they found that teaching and learning of Mathematics in Japan were in very high quality and effective. Stigler \& Hiebert, 1999 stated in the book "The Teaching Gap", a TIMSS video study analysis showed that factors contributing 
to high achievement in Japanese teachers in the classroom were due to Lesson Study practices among them.

Development of Lesson Study in Malaysia has been introduced under the Professional Learning Community (PLC) program which is based on five key strategies to support and improve student achievement. These include Learning Walk, Peer Coaching, Teacher Sharing Session and Lesson Study (Zanaton Iksan et.al, 2017). Even though Lesson Study methods are often applied in teaching and learning of Science and Mathematics subjects (Nur Ain Elzira \& Zamri, 2019) but also looks capable to enhance teachers' understanding, skills and creativity in planning more effective teaching and learning of History subjects. This is because there is a problem among History teachers that they are not creative in preparing the Daily Lesson Plan and still tied to traditional patterns of teaching practice. More creative and innovative teaching processes are needed to produce effective teaching and learning proses. The collaborative method can be implemented by History teachers through group discussions and study to discuss and elaborate on issues that arise in the teaching and learning process of History subjects. This will help to enhance the quality of teaching of History teachers to make a positive impact on the student learning process and indirectly helps students to achieve their learning objectives effectively. Therefore, the benefits of the practice should be nurtured and strengthened continually to be a culture of work by all teachers in the school especially the History teachers.

\section{Implementation of Lesson Study in History subject}

Since the effectiveness of the Lesson Study practice has been proven in several subjects in our country, the Lesson Study approach can also be used as an alternative to strengthen teaching and learning practices in the History subject. According to Rohaida \& Zamri (2015), several steps need to be taken in Lesson Study practice. First, the History teacher needs to form a group among the members of the History Committee and further define the goals that they want to achieve. A group leader will be appointed to coordinate all related activities. Next, each group member should study and discuss the History syllabus and the difficult topics. After the discussion, History teachers will need to set the learning objectives that they want to achieve in the Lesson Study process. The second step is to create a Daily Teaching Plan. In this process, the History teacher will discuss in a group setting the teaching activities in the sequence starting from the teaching steps, teaching aids and the methods and also the strategies that will be implemented. Next, a team member should be appointed to be the model teacher in the teaching process.
The next step begins when the teaching session started. The model teacher will conduct the teaching and learning sessions according to the Daily Teaching Plan. Currently, other members of the group need to make observations. To gain a better understanding of the teaching and learning process, some experts should be invited to observe. All observers will collect data during a teaching and learning session for reflection purposes. The primary focus of the observer should be on student achievement and behaviour. The next step is to conduct a reflection session. Reflections will be made once the teaching and learning process is completed. Model teachers will reflect on student achievement first, then followed by the views, suggestions, criticisms, and criticisms of the group members and invited experts. Detailed discussions need to be made for improvement purposes. The last step to take is to change the Daily Teaching Plan. The leader of the group will record all the observations, changes that need to be made and reflection for future reference. The cycle to be run by this History teacher is as described by Zanaton et al. (2014). This collaborative process among History teachers should be implemented as it will further enhance the effectiveness of the teaching and learning process of History subjects while improving student achievement. Besides that, it will also promote the spread of knowledge, variety of Historical Thinking Skills and creativity among History teachers.

\subsection{Knowledge Improvement}

Implementing a collaborative Lesson Study method among History teachers will provide many benefits. These include improvements in aspects of knowledge related to specified History syllabus. Collaborative discussions can contribute to the widely sharing of knowledge. There are History teachers who carry out the teaching and learning process based on textbooks only (Sharipah \& Arba'iyah, 2016). They did less research and less reading academic material to add their knowledge in History. This will limit their knowledge. Thus, through the Lesson Study method, the knowledge enhancing process will happen during the discussion to make sure the Daily Study Plan take place. An experienced History Teacher will provide various ideas and share information on the topics that will be carried out. This matter was also discussed by Rohaida \& Zamri (2015) whose stated that the implementation of the Lesson Study can overcome the problem of less-skilled teachers in the teaching and learning process.

\subsection{Variety of Historical Thinking Skills}

Lesson Study practices will also provide opportunities for History teachers to improve and develop their History Thinking Skills in the teaching and learning process and enhance student understanding. Teachers will have the 
opportunity to explore the elements of Historical Thinking skills such as understanding the chronology, exploring the evidence, interpreting, imagining and rationalizing (Mohamad Ikhwan Izam \& Anuar Ahmad, 2018). Through Lesson Study, History teachers will collaborate among them to develop the best skills they can use in their teaching and learning sessions. Besides, this collaborative method provides the opportunity for History teachers to change from traditional methods to more effective methods. Teachers will also no longer carry out teacher-centered activities. Teachers will start to be exposed to student-centered skills. Also, teachers will become more proficient with the variety of skills acquired through Lesson Study. This opinion was supported by Muzirah Ab Mokhti \& Nurhana M Rafiuddin (2013) who stated that Lesson Study practice among teachers has had a significant impact on teachers' confidence in the skills used and will gain effective teaching strategies.

\subsection{Creativity}

Lesson Study practices are also helpful in helping increase the creativity of History teachers. It is a good idea because most of the teachers who have long served are still tied to the traditional method of teaching and learning. Their ideas for a variety of activities in teaching are also limited. These collaborative discussions will help History teachers to choose and present their lessons more creatively. History teachers will be able to use imaginative approaches to make the teaching and learning process more enjoyable and encourage student involvement (Saemah Rahman \& Zamri Mahamod, 2016). History teachers will be good at engaging in more interesting approaches such as role-playing, forums, discussion and visiting places of study. Discussions between History teachers will be of benefit as this aspect of creativity will come from experienced teachers with a wide range of skills. This will assist teachers in the teaching aspect as well as improve student achievement. Creative teachers will be able to raise the student's interest in understanding and accepting the History subject. Students will also be excited and enjoy learning the History subject.

\section{Proposal}

The implementation of Lesson Study should be widely conducted in the subject of History. This can be realized if the History teacher clearly understands the Lesson Study method. History teachers should be given extensive exposure such as attending various workshops and courses that explain the importance and implementation of Lesson Study. Nur Assyura et al. (2019) conducted a study on the Lesson Study method among Islamic Education teachers. The study found that the lack of Lesson Study uses among Islamic Education teachers due to lack of exposure and full understanding of the Lesson Study method. Lack of exposure makes this method difficult and unsuccessful and teachers are unable to carry out the learning sessions as planned. Besides, History teachers also need to be more open to implementing collaborative teaching and learning. Perception of History teachers towards Lesson Study also needs to be noted so that History teachers understand that the purpose of implementing Lesson Study is not to monitor teachers but to see student achievement. The involvement of all parties is essential to the implementation of the Lesson Study to achieve the objectives set. Principals and administrators need to play their role in encouraging History teachers to involve in Lesson Study practices. The history teacher's timetable also needs to be adjusted for Lesson Study practice. While Excellent History Teachers are also required to present and share relevant Lesson Study practices in surrounding schools. This collaboration should also involve professionals such as university professors and lecturers. This will give History teachers a chance to run the Lesson Study cycle smoothly.

\section{Conclusion}

Teachers' role is seen as the main factor in the efforts of transforming the education of the nation. Teachers should always be committed and strive to improve the quality of their teaching. It is hoped that this concept paper will provide an understanding of the importance of Lesson Study practices that need to be implemented systematically and continuously by History teachers. This method will help History teachers to implement the teaching and learning process effectively. The problem of History teachers related to knowledge, skills, and levels of creativity will also be resolved. Besides, it also shows positive developments in the effectiveness of the teaching and learning process as well as enhancing student interest and achievement of students in History subjects. Therefore, research on the importance of Lesson Study Practice in the History subject should be conducted and will help to improve the professionalism of teachers. It has been proved that Lesson Study practices will give a huge impact on increasing and sustainable the teaching quality of teachers and student learning in the long term. This study will add the collection of academic reference materials that will assist researchers in developing national education. Lesson Study is a solution to the problem among the teachers especially History teachers. With this impact, the problem of unskilled teachers and lack of knowledge to teach the History subject is no longer a doubt as the teachers can learn it in groups. Indirectly, the constraints and challenges faced by History teachers will be addressed.

\section{References}


[1] Ahamad Rahim \& Sidek Said. 2012. Pelaksanaan Kurikulum Sejarah Menengah Rendah di Malaysia-Satu Penilaian. Seminar Kebangsaan Majlis Dekan Pendidikan IPTA.

[2] Malar, M. 2010. Membanding Kesan Kaedah Lima Fasa Needham, Kaedah STAD dan Kaedah Konvensional Terhadap Pencapaian, Kemahiran Sosial dan Minat Murid Dalam Pembelajaran Sejarah Tingkatan Empat. Tesis bagi memenuhi keperluan bagi Ijazah Doktor Falsafah, Pusat Pengajian Ilmu Pendidikan, Universiti Sains Malaysia.

[3] Mohamad Ikhwan Izam \& Anuar Ahmad. Kemahiran Pemikiran Sejarah dalam Pengajaran dan Pembelajaran Mata Pelajaran Sejarah. Proceeding International Conference on Social Studies \& Humanities (ICOSH 2018): 9-19.

[4] Muzirah Ab Mokhti \& Nurhana Mohamad Rafiuddin. 2013. Persepsi Guru Sains yang mengamalkan Lesson Study sebagai Program Pembangunan Profesional Guru terhadap keberkesanan pengajaran dan pembelajaran. Proceeding of the Global Summit on Education: 516-534.

[5] Norakma Mohd Daud, Abdul Razak Ahmad \& Noria Munirah Yakub. 2015. Pembelajaran Berteraskan Kemahiran Berfikir Aras Tinggi (KBAT) di dalam Pengajaran dan Pembelajaran mata pelajaran Sejarah. Proceeding $7^{\text {th }}$ International Seminar on Regional Education: 352-360.

[6] Nur Ain Elzira Abdullah \& Zamri Mahamod. 2019. Kajian Pembelajaran Pembangunan Profesional Berterusan. Bangi: Penerbit Universiti Kebangsaan Malaysia.

[7] Nur Assyura Ahmad Nasir, Hafizhah Zulkifli, Maimun Aqsha Lubis \& Rohana Misran. 2019. Kaedah Lesson Study dalam kalangan guru Pendidikan Islam bagi mata pelajaran Pendidikan Islam. The $12^{\text {th }}$ Internasional Workshop and Conference of Asean Studies in Islamic and Arabic Education, Linguistics, Social Sciences and Educational Technology: 489-495.

[8] Rafidah Yulo \& Abdul Razak Ahmad. 2019. Role Play sebagai Alternatif dalam PdPc Sejarah. Seminar Wacana Pendidikan: 281-295.

[9] Rajamani Palaniappan. 2017. Permainan Teka Silang Kata dalam Proses Pengajaran dan Pembelajaran Sejarah. International Conference on Education and Regional Development 2017 (ICERD 2017): 219-225.

[10] Rohaida Mazlan \& Zamri Mahamod. 2015. Amalan Kajian Pembelajaran (Lesson Study) dalam kalangan guru Bahasa Melayu: satu cadangan. Prosiding Seminar Kebangsaan Pendidikan Negara Kali Ke-5: 38-44.

[11] Rohaiza Abd Thani \& Norasmah Hj Othman. 2017. Lesson Study dan Pengajaran Guru. Seminar Penyelidikan Pendidikan: 340-349.
[12] Saemah Rahman \& Zamri Mahamod. 2016. Kreativiti dalam Pengajaran dan Pembelajaran. Bangi: Penerbit Universiti Kebangsaan Malaysia.

[13] Sharipah Aini Jaafar \& Arbai'yah Mohd Noor. 2016. Pelaksanaan Pengajaran dan Pembelajaran Sejarah di Sekolah-sekolah di Malaysia, 1957-1989. SEJARAH (Journal of the Departmment of History), No.25, Bil.2: 40-57.

[14] Zanaton Iksan, Effandi Zakaria \& Md Yusoff Daud. 2014. Model of Lesson Study approach during micro teaching. International Education Studies 7(13): 25-33.

[15] Zanaton Iksan. (Pnyt). 2017. Pembelajaran Kolaboratif Guru. Bangi: Penerbit Universiti Kebangsaan Malaysia.

[16] Zarina Md. Zain \& Zanaton Iksan. 2014. Perbandingan antara Lesson Study dan Kajian Tindakan. The $4^{\text {th }}$ International Conference on Learner Diversity (ICELD 2014): 279-289. 